\title{
DEVELOPMENT OF QUANTITATIVE HPTLC-DENSITOMETRY METHODS FOLLOWING A MODEL APPROACH FOR TRANSFER OF TLC SCREENING METHODS FOR PHARMACEUTICAL PRODUCTS OF METFORMIN HCL, POTASSIUM CLAVULANATE, CAFFEINE, FLUOXETINE HCL, AND GABAPENTIN
}

\section{KAITLIN NGUYEN ${ }^{a}$, DANHUI ZHANG ${ }^{b}$ and JOSEPH SHERMA ${ }^{a *}$}

\begin{abstract}
Transfer of thin-layer chromatography Global Pharma Health Fund Minilab kit protocols for detecting counterfeit drugs in pharmaceutical products in the field to quantitative high-performance TLC (HPTLC)-densitometry methods was carried out for potassium clavulanate and metformin $\mathrm{HCl}$ using a model process published earlier. HPTLC-densitometry methods were also developed following the model process for caffeine, fluoxetine $\mathrm{HCl}$, and gabapentin, for which methods are not included in the Minilab manual. The model process involves use of EMD Millipore Premium Purity silica gel $60 F_{254}$ plates, automated sample and standard solution application with a CAMAG Linomat 4, and automated densitometry with a CAMAG Scanner 3 for determination of peak purity and identification and for quantification. Detection methods for counterfeit samples of the three drugs not covered in the Minilab manual were also developed and posted online with open access as supplemental methods for the Compendium of Unofficial Methods for Rapid Screening of Pharmaceuticals by Thin Layer Chromatography.
\end{abstract}

Keywords: thin layer chromatography, drug analysis, metformin $\mathrm{HCl}$, potassium clavulanate, gabapentin, fluoxetine $\mathrm{HCl}$, caffeine

\footnotetext{
a Department of Chemistry, Lafayette College, Easton, PA, USA

${ }^{b}$ Department of Chemical and Biomedical Engineering, Lafayette College, Easton, PA, USA

*Corresponding author: shermaj@lafayette.edu
} 


\section{INTRODUCTION}

A model process was previously described [1-3] for transfer of qualitative/semiquantitative thin-layer chromatography (TLC) screening methods for pharmaceutical products with quality defects contained in the Global Pharma Health Fund E.V. (GPHF) Minilab manual [4] or U.S. Food and Drug Administration Compendium of Unofficial Methods for Rapid Screening of Pharmaceuticals by Thin Layer Chromatography [5] to quantitative highperformance TLC (HPTLC)-densitometry methods. The model process was applied earlier to formulations containing acetylsalicylic acid, acetaminophen, ibuprofen, and chlorpheniramine maleate [1]; mebendazole, diphenhydramine $\mathrm{HCl}$, amodiaquine, and artesunate [2]; amodiaqine and diazepam [3]; lumefantrine + artemether [6]; albendazole, amodiaquine + artesunate [7]; pyrazinamide + ethambutol + isoniazid + rifampicin [8]; quinine sulfate, mefloquine, and dihydroartemisinin + piperaquine phosphate [9]; azithromycin, imipramine $\mathrm{HCl}$, and sulfadoxine + pyrimethamine [10]; clarithromycin, azithromycin, and amodiaquine + artesunate [11]; and cefixime, cefuroxime axetil, cephalexin hydrate, ciprofloxacin $\mathrm{HCl}$, levofloxacin, and metronidazole [12].

The model process comprises sample and standard preparation, establishment of a linear or polynomial calibration curve covering $70-130 \%$ of the label value, assay of three samples of the pharmaceutical product relative to the label value each in triplicate, evaluation of the accuracy of the method using standard addition analysis at 50,100 , and $150 \%$ fortification levels each in triplicate, and peak purity and peak identity tests; only certain relatively nontoxic solvents can be used for standard and sample solution and mobile phase preparation. In this article, we report the use of the model process to transfer TLC Minilab methods to HPTLC-densitometry for pharmaceutical products containing the diabetes medication metformin $\mathrm{HCl}$ (CAS No. 111570-4) and antibiotic potassium clavulanate (CAS No. 61177-45-5), as well as to develop HPTLC-densitometry methods for the products containing the stimulant caffeine (CAS No. 58-08-2), the nerve pain and anticonvulsant medication gabapentin (CAS No. 60142-96-3), and the antidepressant fluoxetine $\mathrm{HCl}$ (CAS No. 56296-78-7) for which there are no Minilab or Compendium methods published.

\section{RESULTS}

Results of the method development for the five pharmaceutical products are displayed in Table 1 for the assay of the three tablets and in Table 2 for the validation analyses. The optimal regression mode for assays and validation of each was chosen based on the best calibration curve r-values, 
assay values closer to the label value, accuracy of the standard addition validation, and lower relative standard deviations (RSDs) for the replicated analyses. Calibration curve r-values in our assay and validation experiments were at least 0.99 ; all validation analysis recoveries at 50,100 , and $150 \%$ spike levels were within $+/-5 \%$; and peak purity and identity r-values were 0.99 consistent with the model process requirements. All assays were within $85-115 \%$ specification limits of the label value as specified by the U.S. Pharmacopeia (USP) for individual dosage form analysis except for the one high assay result of the potassium clavulanate tablets. RSDs for triplicate assays and validation analyses were within the required $3 \%$ except for the $100 \%$ spike level for gabapentin.

Table 1. Assay results for pharmaceutical products containing caffeine, fluoxetine $\mathrm{HCl}$, gabapentin, metformin $\mathrm{HCl}$, potassium clavulanate respectively

\begin{tabular}{|c|c|c|c|c|c|c|c|}
\hline & \multicolumn{2}{|c|}{ Tablet 1 } & \multicolumn{2}{c|}{ Tablet 2 } & \multicolumn{2}{c|}{ Tablet 3 } \\
\hline $\begin{array}{c}\text { Pharmaceutical } \\
\text { product }\end{array}$ & $\begin{array}{c}\text { Regression } \\
\text { mode }\end{array}$ & $\begin{array}{c}\text { Assay } \\
(\%)\end{array}$ & $\begin{array}{c}\text { RSD } \\
(\%)\end{array}$ & $\begin{array}{c}\text { Assay } \\
(\%)\end{array}$ & $\begin{array}{c}\text { RSD } \\
(\%)\end{array}$ & $\begin{array}{c}\text { Assay } \\
(\%)\end{array}$ & $\begin{array}{c}\text { RSD } \\
(\%)\end{array}$ \\
\hline Caffeine & Polynomial & 106 & 0.502 & 113 & 1.39 & 106 & 0.181 \\
\hline Fluoxetine HCl & Linear & 101 & 1.93 & 93.2 & 0.832 & 97.0 & 1.13 \\
\hline Gabapentin & Polynomial & 89.8 & 1.98 & 93.5 & 0.733 & 95.5 & 2.20 \\
\hline Metformin HCl & Linear & 100 & 0.484 & 106 & 1.40 & 105 & 0.547 \\
\hline $\begin{array}{c}\text { Potassium } \\
\text { clavulanate }\end{array}$ & Linear & 101 & 1.74 & 117 & 0.914 & 114 & 0.751 \\
\hline
\end{tabular}

Table 2. Validation results for pharmaceutical products containing caffeine, fluoxetine $\mathrm{HCl}$, gabapentin, metformin $\mathrm{HCl}$, potassium clavulanate respectively

\begin{tabular}{|c|c|c|c|c|c|c|}
\hline & \multicolumn{2}{|c|}{$50 \%$ spike } & \multicolumn{2}{c|}{$\mathbf{1 0 0 \%}$ spike } & \multicolumn{2}{|c|}{$\mathbf{1 5 0 \%}$ spike } \\
\hline $\begin{array}{c}\text { Pharmaceutical } \\
\text { product }\end{array}$ & $\begin{array}{c}\text { Rec. }^{\text {a }} \\
(\%)\end{array}$ & $\begin{array}{c}\text { RSD } \\
(\%)\end{array}$ & $\begin{array}{c}\text { Rec. } \\
(\%)\end{array}$ & $\begin{array}{c}\text { RSD } \\
(\%)\end{array}$ & $\begin{array}{c}\text { Rec. } \\
(\%)\end{array}$ & $\begin{array}{c}\text { RSD } \\
(\%)\end{array}$ \\
\hline Caffeine & 104 & 1.13 & 102 & 2.33 & 104 & 2.28 \\
\hline Fluoxetine $\mathrm{HCl}$ & 100 & 0.700 & 101 & 0.758 & 96.6 & 2.76 \\
\hline Gabapentin & 104 & 1.86 & 103 & 7.42 & 101 & 1.68 \\
\hline Metformin $\mathrm{HCl}$ & 105 & 1.88 & 105 & 0.0777 & 105 & 0.452 \\
\hline $\begin{array}{c}\text { Potassium } \\
\text { clavulanate }\end{array}$ & 103 & 1.81 & 100 & 0.183 & 97.5 & 2.90 \\
\hline
\end{tabular}

${ }^{\text {aRec. }}=$ Recovery 


\section{DISCUSSION}

A direct transfer of Minilab TLC methods to HPTLC-densitometry according to the earlier published process involves use of the same solvents in preparing the sample and standard solutions, application of the same weight of sample and standard in $10.00 \mu \mathrm{L}$ as in $2.00 \mu \mathrm{L}$, and use of the same mobile phase and detection method.

The metformin $\mathrm{HCl}$ Minilab method for a $250 \mathrm{mg}$ tablet (Volume II, Supplement 2014, Method 6.78, pp. 24-27) could not be transferred directly. The Minilab method involves preparation of stock standard and sample solutions in water followed by dilution with methanol to prepare the $100 \%$ standard and sample solutions. The drug was found to precipitate out upon dilution with methanol; therefore dilution was made with water instead. The Minilab mobile phase, methanol-water-glacial acetic acid (15:5:1) did not give tight bands nor symmetrical scan peaks, so the mobile phase methanol-water-1\% (w/v) ammonium chloride reported in the literature [13] was adopted. After testing many mobile phases, none without ammonium chloride as a component gave good results, so it was decided that use of this non-hazardous salt was acceptable. When applying sample and standard weights specified in the Minilab unusually high scan areas $(>10,000)$ were obtained, but calibration, assay, and validation results were within the model process requirements.

The potassium clavulanate-amoxicillin coformulations Minilab method for a product containing $62.5 \mathrm{mg}$ of clavulanic acid (Volume II, Supplement 2013, Method 6.69, pp.20-23) was directly transferred for our product with a label value of $57 \mathrm{mg}$ of clavulanic acid, equivalent to $67.9 \mathrm{mg}$ of potassium clavulanate except for the detection method. Bands were detected by heating the plate after development at $160^{\circ} \mathrm{C}$ for $5 \mathrm{~min}$ to produce fluorescence quenching bands visible under $254 \mathrm{~nm}$ ultraviolet (UV) light rather than using iodine vapor. This reagentless thermochemical activation method involving simple heating of silica gel layers was first reported by our laboratory and has been applied to a variety of drugs and dietary supplements [11]. Assay recovery for one of the three tablets was slightly above the model procedure upper limit of $115 \%$, but the standard addition validation (Table 2) and peak identity and peak purity results meeting requirements indicated the assay was reliable. It was necessary to carefully adjust the integration limits when scanning bands of potassium clavulanate at $254 \mathrm{~nm}$ so that streaked amoxicillin bands did not interfere (Figure 1). Potassium clavulanate was also visible as fluorescent bands after heating, but interference of the amoxicillin bands when they were scanned at $366 \mathrm{~nm}$ was greater than at $254 \mathrm{~nm}$. The reason for the two high assay results, one greater than the $115 \%$ model process limit, is not known, but the good validation results indicate that the assays are accurate and that 
the product, which was obtained without a prescription from a shop in China, contains tablets with variable active ingredient amounts. A simultaneous method for assay of the coformulation could not be developed after unsuccessfully testing many different solvents to extract both potassium clavulanate amoxicillin completely from the sample and standard and mobile phases to separate the two compounds without streaked amoxicillin bands. In addition, after weeks of considerable research we have been unable to successfully use any published HPTLC-densitometry method for determination of amoxicillin, or the similar drug ampicillin, in any pharmaceutical product alone or in a coformulation, or to develop and validate a new method.

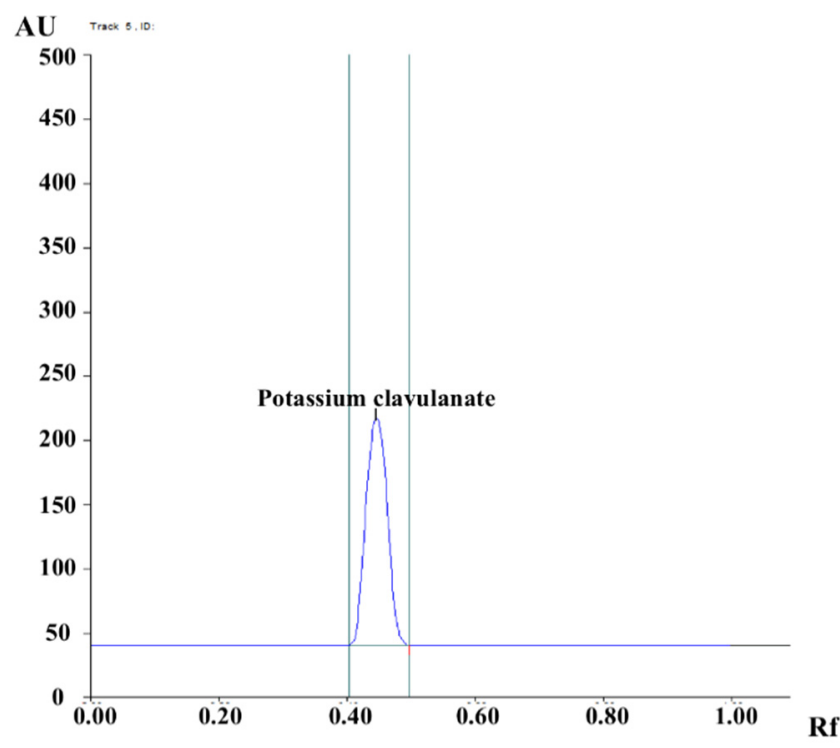

Figure 1. Densitogram of $10.0 \mathrm{uL}$ of potassium clavulanate $100 \%$ sample solution, representing $3.31 \mathrm{ug}$ of potassium clavulanate when interpolated from the calibration curve based on its area.

The model transfer process has also been used earlier as the basis of development of HPTLC-densitometry methods for drug products covered neither in the Minilab manual nor the Compendium, e.g., naproxen sodium, loperamide $\mathrm{HCl}$, and loratidine [14]. In this paper, methods were similarly developed for caffeine, fluoxetine $\mathrm{HCl}$, and gabapentin. Based on the development of these methods, corresponding TLC screening methods were devised, tested, and published in an open access online supplement to the FDA Compendium [15], from which they could be easily transferred to Minilab 
TLC screening methods, if desired, by taking into account the $2.00 \mu \mathrm{L}$ rather than $3.00 \mu \mathrm{L}$ spotting volumes and the usual use of an authentic drug product rather than a commercial standard to prepare the standard solutions for Minilab methods.

The caffeine method for a $200 \mathrm{mg}$ tablet was a direct adaptation of a previously published method [16] that used methanol solvent for standard and sample solution preparation, a similar calibration curve weight range, silica gel HPTLC plates, ethyl acetate-methanol (85:15) mobile phase, and fluorescence quenching detection. The fluoxetine $\mathrm{HCl}$ method for a $20 \mathrm{mg}$ capsule was directly adapted from a published method for alprazolam and fluoxetine $\mathrm{HCl}$ in a tablet formulation [17] with use of methanol solvent for standard and sample solution preparation, acetone-toluene-ammonium hydroxide (6.0:3.5:0.5) mobile phase, and fluorescence quenching detection, but the calibration curve was prepared with weight range about four times greater in order to achieve successful band detection and scanning.

The gabapentin method for an $800 \mathrm{mg}$ tablet was directly transferred from a published method for $200 \mathrm{mg}$ capsules [18] in terms of the use of methanol for standard and sample solution preparation, the same weight range for the calibration curve, and the use of ninhydrin spray reagent for band detection. However, the mobile phase $n$-butanol-water acetic acid (3:3:2) [18] was modified by replacing $n$-butanol with ethanol, which are in the same selectivity group and have a similar solvent strength in Snyder's liquid chromatography solvent classification list [19], because $n$-butanol is not one of the allowed solvents for Minilab or Compendium methods. Unlike potassium clavulanate, heating the plate after development did not produce fluorescence quenching zones to eliminate for the need of a detection reagent, the use of which usually leads to poorer accuracy and precision data in method development.

Depending on the applications of the methods described in this paper, they should be fully validated for parameters such as accuracy, precision (repeatability and intermediate precision), specificity, linearity, range and robustness under relevant guidelines such as those described by the International Conference on Harmonization [20] or subjected to an interlaboratory study [21] to prove that they are suitable for their intended purpose by users.

\section{CONCLUSIONS}

HPTLC-densitometry methods were developed and validated for assay of pharmaceutical formulations of two drugs by transfer of TLC screening methods contained in the Minilab manual, and for formulations of three drugs 
not included in the Minilab manual or FDA Compendium. Supplemental Compendium methods that can be easily converted to Minilab methods if desired were devised for these latter drugs and posted on an open access internet site.

\section{EXPERIMENTAL}

\section{Standard and sample solution preparation}

General preparation procedures were carried out as described earlier [1-3] unless otherwise specified. All standards and ground (by mortar and pestle) tablets or capsule contents were dissolved with the aid of $10 \mathrm{~min}$ each of magnetic stirring and sonication before syringe filtration to remove undissolved excipients prior to further dilution or direct application. Dilutions were made using appropriate volumetric flasks and transfer and measuring pipets. Solutions were stored in sealed vials wrapped in parafilm in a refrigerator. A description of standards and samples and their sources as well as detailed procedures for stock and $100 \%$ working standard and sample solution preparation are shown in Table 3.

Table 3. Preparation of $100 \%$ standard and $100 \%$ sample solutions

\begin{tabular}{|c|c|c|}
\hline $\begin{array}{l}\text { Pharmaceutical } \\
\text { product }\end{array}$ & $100 \%$ standard solution & $100 \%$ sample solution \\
\hline $\begin{array}{c}\text { Caffeine (200 mg; CVS } \\
\text { Pharmacy, Inc., USA) }\end{array}$ & $\begin{array}{l}0.400 \mu \mathrm{g} / 10.0 \mu \mathrm{L} \text { : dissolve } \\
40.0 \mathrm{mg} \text { standard (Sigma- } \\
\text { Aldrich, St. Louis, MO, } \\
\text { Catalog No. C0750) in } 100 \mathrm{~mL} \\
\text { methanol, then dilute } 1.00 \mathrm{~mL} \\
\text { with } 9.00 \mathrm{~mL} \text { methanol }\end{array}$ & $\begin{array}{l}0.400 \mu \mathrm{g} / 10.0 \mu \mathrm{L}^{\mathrm{a}} \text { : } \\
\text { dissolve a tablet in } \\
100 \mathrm{~mL} \text { methanol, then } \\
\text { dilute } 1.00 \mathrm{~mL} \text { with } \\
49.0 \mathrm{~mL} \text { methanol }\end{array}$ \\
\hline $\begin{array}{c}\text { Fluoxetine } \mathrm{HCl} \\
\text { (20 mg; Aurobindo } \\
\text { Pharma, USA Inc.) }\end{array}$ & $\begin{array}{l}4.01 \mu \mathrm{g} / 10.0 \mu \mathrm{L} \text { : dissolve } \\
80.1 \mathrm{mg} \text { standard (Sigma- } \\
\text { Aldrich, No. PHR1394) in } \\
200 \mathrm{~mL} \text { methanol }\end{array}$ & $\begin{array}{c}4.00 \mu \mathrm{g} / 10.0 \mu \mathrm{L}: \\
\text { dissolve a capsule in } \\
50.0 \mathrm{~mL} \text { methanol }\end{array}$ \\
\hline $\begin{array}{c}\text { Gabapentin } \\
\text { (800 mg; Glenmark } \\
\text { Pharmaceuticals Inc., } \\
\text { USA) }\end{array}$ & $\begin{array}{c}1.60 \mu \mathrm{g} / 10.0 \mu \mathrm{L} \text { : dissolve } \\
100 \mathrm{mg} \text { standard (Sigma- } \\
\text { Aldrich, No. PHR1049) in } \\
100 \mathrm{~mL} \text { methanol, then dissolve } \\
16.0 \mathrm{~mL} \text { in } 84.0 \mathrm{~mL} \text { methanol }\end{array}$ & $\begin{array}{c}1.60 \mu \mathrm{g} / 10.0 \mu \mathrm{L}: \\
\text { dissolve a tablet in } \\
100 \mathrm{~mL} \text { methanol, then } \\
\text { dissolve } 1.00 \mathrm{~mL} \text { with } \\
49.0 \mathrm{~mL} \text { methanol }\end{array}$ \\
\hline
\end{tabular}




\begin{tabular}{|c|c|c|}
\hline $\begin{array}{c}\text { Pharmaceutical } \\
\text { product }\end{array}$ & $100 \%$ standard solution & $100 \%$ sample solution \\
\hline $\begin{array}{c}\text { Metformin } \mathrm{HCl} \\
\text { (250 mg; Shanghai } \\
\text { Xinyi Tianping } \\
\text { Pharmaceutical Co., } \\
\text { Ltd, Shanghai, China) }\end{array}$ & $\begin{array}{c}8.00 \mu \mathrm{g} / 10.0 \mu \mathrm{L} \text { : dissolve } \\
40.0 \mathrm{mg} \text { standard } \\
(\text { Sigma-Aldrich, No. } \\
\text { PHR1084) in } 50.0 \mathrm{~mL} \\
\text { deionized water }\end{array}$ & $\begin{array}{c}8.00 \mu \mathrm{g} / 10.0 \mu \mathrm{L}: \\
\text { dissolve a tablet with } \\
25.0 \mathrm{~mL} \text { deionized water, } \\
\text { then dilute } 2.00 \mathrm{~mL} \text { with } \\
23.0 \mathrm{~mL} \text { deionized water }\end{array}$ \\
\hline $\begin{array}{c}\text { Potassium clavulanate } \\
\text { (67.9 mg }{ }^{\text {b }} \text { Guangzhou } \\
\text { Baiyunshuan } \\
\text { Pharmaceutical } \\
\text { Holdings Co., Ltd, } \\
\text { China) }\end{array}$ & $\begin{array}{l}2.72 \mu \mathrm{g} / 10.0 \mu \mathrm{L} \text { : dissolve } \\
34.0 \mathrm{mg} \text { standard (Sigma- } \\
\text { Aldrich, No. } 33454 \text { ) in } \\
25.0 \mathrm{~mL} \text { deionized water, } \\
\text { then dilute } 1.00 \mathrm{~mL} \text { with } \\
4.00 \mathrm{~mL} \text { deionized water }\end{array}$ & $\begin{array}{c}2.72 \mu \mathrm{g} / 10.0 \mu \mathrm{L}: \\
\text { dissolve a tablet in } \\
50.0 \mathrm{~mL} \text { deionized } \\
\text { water, then dilute } \\
1.00 \mathrm{~mL} \text { with } 4.00 \mathrm{~mL} \\
\text { deionized water }\end{array}$ \\
\hline
\end{tabular}

${ }^{a}$ Concentrations indicated for $100 \%$ sample solutions are theoretical concentrations.

b The potassium clavulanate sample was a tablet of $57 \mathrm{mg}$ clavulanic acid (or $67.9 \mathrm{mg}$ potassium clavulanate, when adjusted for molecular weight factor) with $400 \mathrm{mg}$ amoxicillin as the other active ingredient.

\section{HPTLC}

Detailed HPTLC-densitometry methods and instruments were described earlier [1-3, 6-12]. Silica gel $60 \mathrm{~F}_{254}$ Premium Purity HPTLC glass plates $(20 \times 10$ $\mathrm{cm}$; EMD Millipore Corp., Billerica, MA, a division of Merck KGaA, Darmstadt, Germany; Part No. 1.05648.0001) were used as received. Application of $7.00,9.00,11.0$, and $13.0 \mu \mathrm{L}$ aliquots of the $100 \%$ standard solution of each drug [representing $70-130 \%$ of the active pharmaceutical ingredient (API) content based on label value] and triplicate $10.0 \mu \mathrm{L}$ aliquots of $100 \%$ sample solution were applied using a CAMAG (Wilmington, NC, USA) Linomat 4 spray on applicator [band length $6 \mathrm{~mm}$, application rate $4 \mathrm{sec} / \mu \mathrm{L}(15 \mathrm{sec} / \mu \mathrm{L}$ for solutions containing water), table speed $10 \mathrm{~mm} / \mathrm{s}$, distance between bands $4 \mathrm{~mm}$, distance from the left edge of the plate $17 \mathrm{~mm}$, and distance from the bottom of the plate $1 \mathrm{~cm}$ ). HPTLC-densitometry in the absorption-reflectance mode was performed using a CAMAG Scanner $3(4.00 \times 0.45 \mathrm{~mm}$ Micro slit dimensions, $20 \mathrm{~mm} / \mathrm{s}$ scan rate). The mobile phases used for the five pharmaceutical products and drug $R_{f}$ values are shown in Table 4 . The fluorescence-quenching bands were scanned with $254 \mathrm{~nm}$ UV light, and the colored bands of gabapentin were scanned with $510 \mathrm{~nm}$ light. The Scanner 3 winCATS software automatically created calibration curves (linear or $2^{\text {nd }}$ order polynomial) based on scan areas versus standard weights applied, interpolated 
weights of drugs in bracketed samples based on scan areas, and tested peak purity and identity of the sample based on spectral comparison. Accuracy of the developed methods was validated by using standard addition with a 70$130 \%$ calibration curve as described earlier [3].

Table 4. Mobile phases selected in our methods for pharmaceutical products containing caffeine, fluoxetine $\mathrm{HCl}$, gabapentin, metformin $\mathrm{HCl}$, potassium clavulanate respectively

\begin{tabular}{|c|c|c|}
\hline $\begin{array}{c}\text { Pharmaceutical } \\
\text { product }\end{array}$ & Mobile phase $^{\mathrm{a}}$ & $\mathrm{R}_{\mathrm{f}}$ \\
\hline Caffeine & Ethyl acetate-methanol $(85: 15)$ & 0.36 \\
\hline Fluoxetine $\mathrm{HCl}$ & Acetone-toluene-ammonia $(6: 3.5: 0.5)$ & 0.62 \\
\hline Gabapentin & $\begin{array}{c}\text { Ethanol-deionized water-glacial acetic acid } \\
(3: 3: 2)\end{array}$ & 0.75 \\
\hline Metformin $\mathrm{HCl}$ & $\begin{array}{c}\text { Methanol-water-1\% ammonium chloride solution } \\
(5: 4: 1)\end{array}$ & 0.25 \\
\hline Potassium clavulanate & Ethyl acetate-glacial acetic acid-water $(15: 5: 5)$ & 0.43 \\
\hline
\end{tabular}

${ }^{\text {a } A l l}$ solutions are shown in volume proportions

\section{ACKNOWLEDGEMENTS}

The authors thank Dave Lentz of EMD Millipore Corp. for providing the Premium Purity glass HPTLC plates used in our experiments. Kaitlin Nguyen was supported by the EXCEL Scholars Program. Danhui Zhang was supported by a Camille and Henry Dreyfus Foundation Senior Scientist Mentor Program award to Professor Joseph Sherma and by the Lafayette College EXCEL Scholars Program.

\section{REFERENCES}

1. C. O'Sullivan, J. Sherma, Acta Chromatographica, 2012, 24, 241.

2. K. Lianza, J. Sherma, Journal of Liquid Chromatography \& Related Technologies, 2013, 36, 2446.

3. N. Popovic, J. Sherma, Acta Chromatographica, 2014, 26, 615.

4. http://www.gphf.org

5. A.S. Kenyon, T.P. Layloff, http://www.pharmweb.net/pwmirror/library/tlc/tlcall.pdf

6. M. Nguyen, J. Sherma, Trends in Chromatography, 2013, 8, 131.

7. M. Nguyen, J. Sherma, Journal of Liquid Chromatography \& Related Technologies, 2014, 37, 2956. 
8. J. Strock, M. Nguyen, J. Sherma, Journal of Liquid Chromatography \& Related Technologies, 2015, 38, 1126.

9. J. Strock, M. Nguyen, J. Sherma, Acta Chromatographica, 2016, 28, 363.

10. D. Zhang, J. Strock, J. Sherma, Journal of Liquid Chromatography \& Related Technologies, 2016, 39, 277.

11. E. Armour, J. Sherma, Journal of Liquid Chromatography \& Related Technologies, 2017, 40, 282.

12. D. Zhang, E. Armour, J. Sherma, Acta Chromatographica, doi:10.1556/1326.2016.29409.

13. H. Mahgoub, R.M. Youssef, M.A. Korany, E.F. Khamis, M.F. Kamal, Drug Development and Industrial Pharmacy, 2014, 40, 1190.

14. D. Zhang, J. Strock, J. Sherma, Trends in Chromatography, 2016, $10,1$.

15. Supplement to a Compendium of Unofficial Methods for Rapid Screening of Pharmaceuticals by Thin Layer Chromatography, http://www.layloff.net.

16. D. Ruddy, J. Sherma, Acta Chromatographica, 2002, 12, 143.

17. R.B. Patel, M.R. Patel, M.B. Shankar, K.K. Bhatt, Journal of AOAC International, 2009, 92, 1082.

18. R.T. Sane, U. Pendse, A. Moghe, S, Khedkar, P. Patil, Indian Drugs, 2003, 40, 547.

19. T. Tuzimski, Selection of the Type of Mobile Phases for Analysis of Nonionic Analytes: Reversed and Normal Phase HPLC, in High Performance Liquid Chromatography in Pesticide Residue Analysis, T. Tuzimski and Joseph Sherma (Editors), CRC Press, Taylor \& Francis Group, 2015, Chapter 7, pp. 174-175.

20. K. Ferenczi-Fodor, Z. Vegh, A. Nagy-Tuak, B. Renger, M. Zeller, Journal of AOAC International, 2001, 84, 1265.

21. E. Kaale, P. Risha, E. Reich, T. P. Layloff, Journal of AOAC International, 2010, 93, 1836. 